\title{
Engineering geological problems of shear and fault zones in Nepal Himalaya
}

\author{
Subas Chandra Sunuwar \\ Butwal Power Company Limited, Kathmandu, Nepal \\ (Email: subas.sunuwar@bpc.com.np)
}

\begin{abstract}
Shear zones and faults pose serious engineering geological problems to the development of infrastructures. The problems are related to the contrasting properties of such zones which contain a weak matrix and strong rock fragments. Shear zones and faults are also frequently affected by groundwater.

In this paper an attempt has been made to classify the shear or fault zones from an engineering geological point of view. The geotechnically problematic brittle shear or fault zones are generally sheared, shattered, powdered, or folded. They contain lenticular to angular fragments and randomly orientated rock clasts supported by a soft and weak matrix. They are further divided into clayey and blocky types. Some problems induced by such shear or fault zones in various hydropower and road projects of Nepal are also discussed.
\end{abstract}

\section{INTRODUCTION}

A serious engineering geological problems in the development of infrastructures arise from shear or fault zones. The problems related to such zones are due to their contrasting properties of the weak matrix and strong rock fragments within it. The shear zones and faults are also frequently affected by groundwater. In engineering practices, only the strength of weaker matrix is generally considered and it can lead to a very conservative and costly design. Thus a great field of research is open on the shear zones and faults of the Himalaya where a large number of hydropower projects with tunnels and dam foundations, mountain roads, and other infrastructures are being developed rapidly.

Little is known about the engineering geological properties of faults or shear zones owing to their extreme complexity. Consequently, the infrastructures in such zones face with serious problems of slope instability, structural failure, overbreak, and rock squeezing, which delay the construction schedule, increases the project cost, and even may cause the loss of life. Therefore an engineering geological study to identify them is essential before the construction of infrastructures. In this paper an attempt has been made to classify the shear or fault zones from the engineering geological perspective, and some problems induced by them in various hydropower and road projects of Nepal are also discussed.

\section{SHEAR OR FAULT ZONES}

The Himalaya was formed as a result of collision of the Indian plate with the Tibetan plate about 50 million years ago. The Indian plate is constantly moving towards the north at a rate of about $50 \mathrm{~mm}$ annually. Major shear or fault zones were developed due to the continuous thrusting of the Indian plate into the Tibetan plate to accommodate shortening. Besides the major faults there are several minor shear or fault zones in the Himalaya.

Geologically, Nepal is divided into the following tectonic units from south to north respectively: (i) Terai, (ii) Siwaliks, (iii) Lesser Himalaya, (iv) Higher or Greater Himalaya, and (v) Tibetan-Tethyan zone (Fig. 1). In Nepal, they extend essentially from east to west and are oriented parallel to the foliation or bedding. The Main Central Thrust (MCT), the Main Boundary Thrust (MBT), and the Main Frontal Thrust (MFT) are the north-dipping major structural breaks in the Himalaya. The MBT and MFT are active faults, which create major difficulties during the construction of infrastructures. On the other hand the MCT is not active and does not pose a major problem. Apart from them, there are several minor shear or fault zones whose thickness ranges from a few metres to tens of metres. Some examples are the Barigad Fault, Talamarang Fault, Baseri Fault, and Dhabang Fault. Other examples of such zones from road sections are the landslides of Kerabari, Dolalghat, and Malekhu. Similarly, overbreak and rock squeezing in the tunnels of Khimti, Modi, Chilime, and Puwa Khola (Sunuwar 2003) are some problems generated by such shear or fault zones.

\section{TYPES OF SHEAR OR FAULT ZONE}

Generally two types of shear or fault zone can be identified in the Nepal Himalaya according to their engineering geological properties (Fig. 2). 


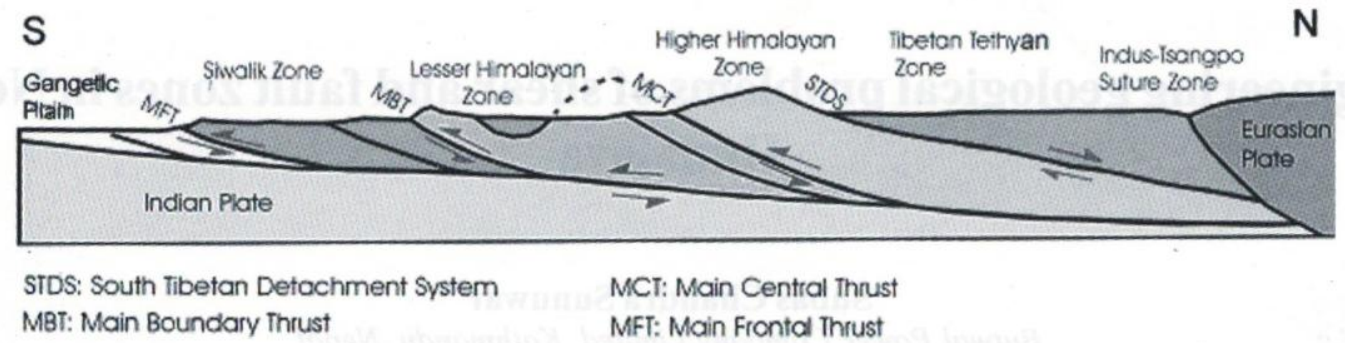

Fig. 1: Schematic geological section of the Nepal Himalaya

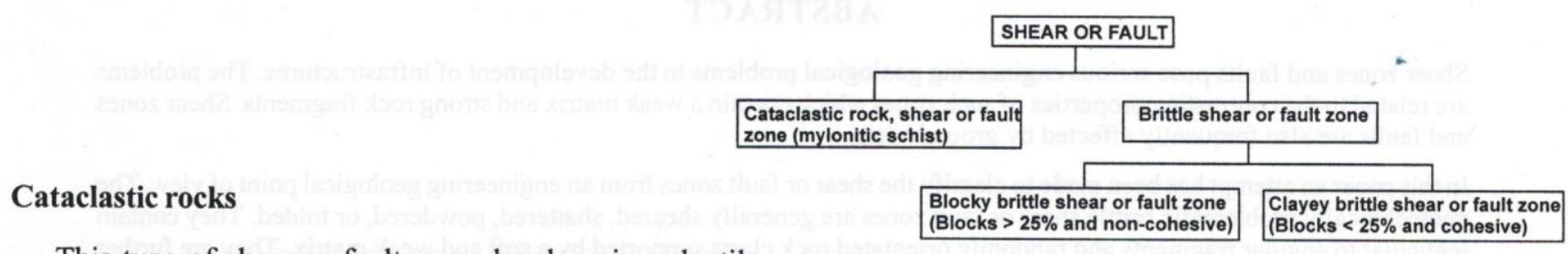

This type of shear or fault zone develops in a ductile rock in deeper parts of the crust, where metamorphic conditions prevail. It is characterised by a thick zone of cataclastic rocks. The MCT is a good example of it. Mylonitic schists are another example of this type of shear or fault zone, which consists mostly of lenticular clasts supported by finer matrix (Fig. 3). Since both clasts and matrix have similar engineering properties due to metamorphism, this type of shear or fault zone is not very problematic in the construction of infrastructures.

\section{Brittle shear or fault zone}

Brittle shear or fault zones are sheared, shattered, powdered, or folded and contain lenticular to angular fragments and randomly orientated rock clasts supported by a soft and weak matrix (Fig. 4). The matrix frequently consists of highly sheared and decomposed fine-grained clayey and silty gouge. This type of shear or fault zone has contrasting properties owing to its weak matrix and strong rock clasts. In addition groundwater also plays a role in developing its heterogeneity. The behaviour of such a shear or fault zone depends on the proportion of soft matrix (clay or sand) and strong clasts. Due to the shearing effect the material is porous and acts like an aquifer as well as an aquiclude. The amount of water in the shear or fault zone depends on the percentage of clay content within it - greater the proportion of clay, less the water content. However a more clayey zone may hold much water immediately above it, making excavation a very risky task.

The brittle shear or fault zone is further divided into the blocky and clayey types according to the volumetric proportion of clasts and matrix (Fig. 2). In general if the volumetric content of clasts is below $75 \%$ the strength and deformation properties of such a zone are governed primarily by the properties of the matrix (Medley 1998). On the other hand, if the volumetric content of clasts exceeds $75 \%$, the

Fig. 2: Engineering geological classification of shear or fault zones

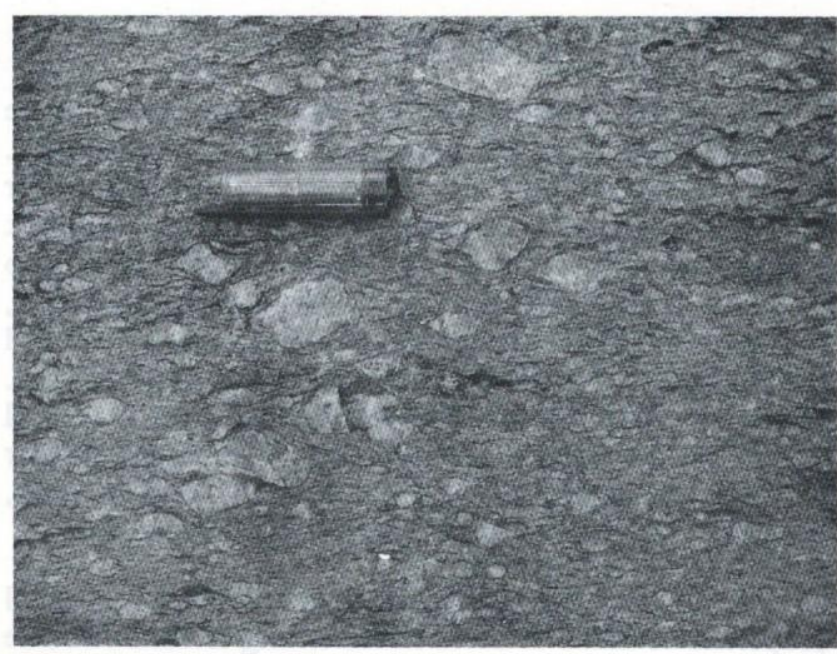

Fig. 3: Cataclastic rock containing clasts and matrix, Khimti IHydropower Project

properties of the zone are no longer controlled by the matrix (Medley 1998). Hence the latter zones are not described here.

\section{Blocky brittle shear or fault zone}

It contains $25-75 \%$ of clasts and generally develops in strong and brittle rocks such as quartzite, dolomite, and gneiss. It is characterised by sheared and shattered rock with strong, angular clasts supported by soft silty sand matrix (Fig. 4). The clay content is low. The size of clasts varies from a few millimetres to a few metres. This type of shear or fault zone bears a huge amount of groundwater. 


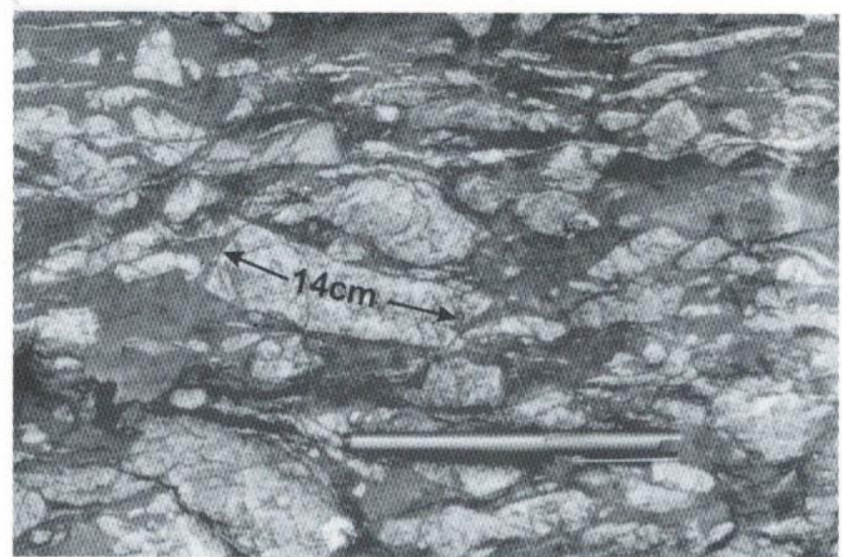

Fig. 4: Brittle shear zone containing about $40 \%$ of rectangular to lenticular clasts and $60 \%$ of weak matrix

\section{Clayey brittle shear or fault zone}

This shear or fault zone generally develops in weak rocks and appears as a very weak, sheared, crenulated, clay-like zone preserving rock textures (Fig. 4). It is also characterised by decomposed rock and clay gouge bands with strong angular clasts (Fig. 5). It contains more than $75 \%$ of clay matrix and less than $25 \%$ of lenticular clasts. Sometimes all sheared and shattered rock fragments are decomposed and altered into clay except strong lenticular clasts. This type of shear or fault zone is generally observed within a single rock type such as schist, phyllite, slate, and mudstone. Its matrix consists mostly of non-swelling type of clay. Though the shear or fault zone itself contains not much water, frequently there is a lot of water just above it.

\section{ENGINEERING GEOLOGICAL PROBLEMS}

Some engineering geological problems related to shear or fault zones in a few road sections and hydropower projects of Nepal are presented below.

\section{Slope stability}

A number of large landslides were triggered by shear or fault zones in Nepal. Some examples are the road sections at Kerabari and Dolalghat, and the Talamarang Landslide. There were severe problems of slope stability at the settling basin of the Kali Gandaki A Hydroelectric Project.

\section{Kali Gandaki Landslide}

Slope stability problems were faced at the backslope of the desander in the Kali Gandaki A Hydroelectric Project due to a $130 \mathrm{~m}$ high slope excavation (Hoek 1999) for the clearance of the structure. The excavated area is made up of lowstrength deformed phyllite and fractured dolomite with a fault underneath. The fault (i.e. plane of weakness) passes through the contact between the dolomite and phyllite. Their bedding and foliation were almost parallel to the excavated

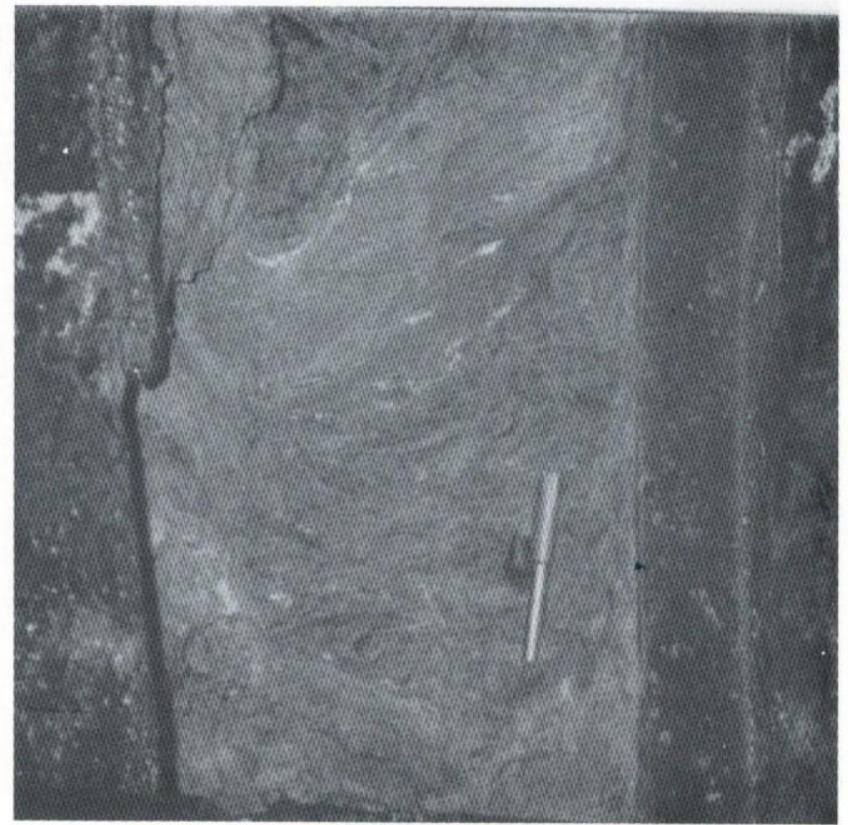

Fig. 5: A clayey brittle shear zone with more than $75 \%$ of clay matrix and less than $25 \%$ of clasts

slope which was prone to sliding (Sunuwar 2005). The excavated slope was supported by a layer of mesh shotcrete with grouted rock bolts. During excavation of the desander backslope in early 1998, a shallow failure occurred and this was followed by a second smaller failure later in the year (Hoek 1999). These failures gave rise to concerns about the overall stability of the backslope during the construction as well as operation period. The original design cut slope was at $1: 1$, which was changed to $1: 1.5$ due to the developed signs of failure. This changed slope again started failing along the fault contact between the phyllite and dolomite. Ultimately, the slope was changed to $1: 1.8$ and it became stable. The change in the design, which altered the originally planned volume of rock excavation of 1.7 million $\mathrm{m}^{3}$ to more than 2.7 million $\mathrm{m}^{3}$, greatly increased the cost of the project (Upreti 2002). The whole project schedule had to be changed, and was partly responsible in delaying the completion of the project by 18 months (Upreti 2002). A lot of effort and a huge amount of money were spent for monitoring and protecting the backslope.

\section{Kerabari Landslide}

The landslide problem on the Butwal-Tansen Road at Hiunde Khola near Karabari was generated by the MBT (Fig. 6). The MBT can be considered to be a blocky brittle shear or fault zone. It is characterised by the sheared and shattered rock with strong, angular clasts supported by soft silty sand matrix. The size of clasts varies from a few millimetres to a few metres. It is more than $60 \mathrm{~m}$ thick. The problems on the road have been encountered since the time of its construction and they are related to the debris flows from upslope, road subsidence, and blockage. Though many retaining structures 


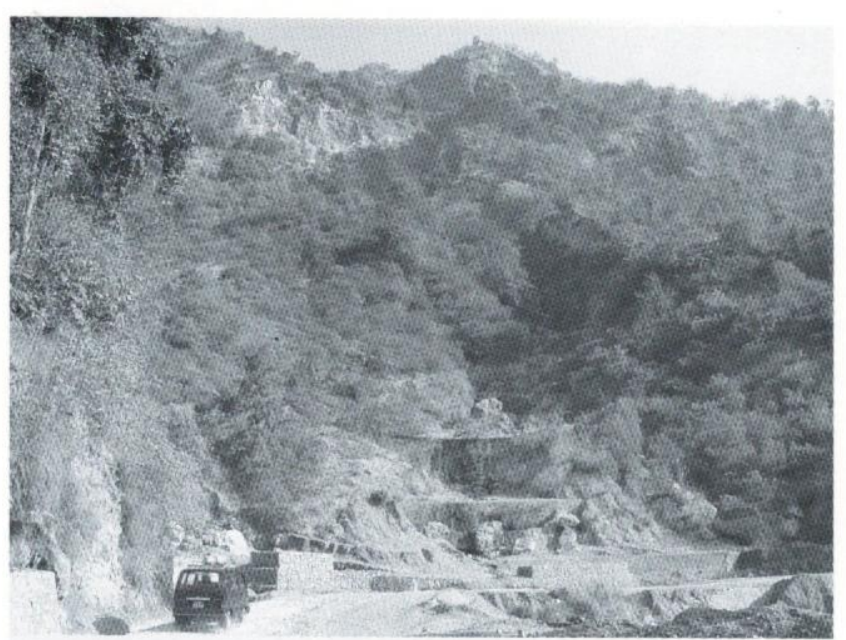

Fig. 6: MBT brittle fault zone on Butwal-Tansen Road at Hiunde Khola near Kerabari

and landslide stabilisation works have been constructed in this stretch, the area is still unstable.

\section{Dolalghat Landslide}

The problems on the Arniko Highway near Dolalghat (Fig. 7) occurred in July 2003 due to road subsidence and blockage by landslide debris. The slide initiated when the toe support was undercut by the Cha Khola. The slide developed on the clayey brittle shear zone which is more than $40 \mathrm{~m}$ thick and characterised by shattered rock with small clasts supported by clay matrix. The shear zone is developed in the Benighat Slates and is observed on both riverbanks. It is steeply $\left(>60^{\circ}\right)$ dipping due north and consists of loose rock fragments with bands of clay gouge.

\section{Overbreak}

Overbreak is a major problem during excavation of a tunnel in a blocky brittle and, to a lesser extent, clayey brittle shear or fault zone. The groundwater erodes its fine matrix and loosens individual clasts. The clasts are gradually separated from their matrix and start to fall. As a result overbreak occurs in a form of ravelling. It generates a number of problems like over excavation and construction time delay.

\section{Khimti I Hydropower Project}

In the Khimti I Hydropower Project, 13 major overbreaks were encountered where the tunnel sections contained brittle shear or fault zones with a considerable amount of seepage (Table 1). These overbreaks delayed considerably the tunnel excavation.

Blocky brittle shear or fault zones may cause catastrophic overbreaks in inclined pressure shafts. Two such overbreaks occurred on 19 April 1997 and 14 July 1998 in the two inclined pressure shafts of the Khimti I Hydropower Project that delayed the construction by 667 days (Sunuwar 2003). The

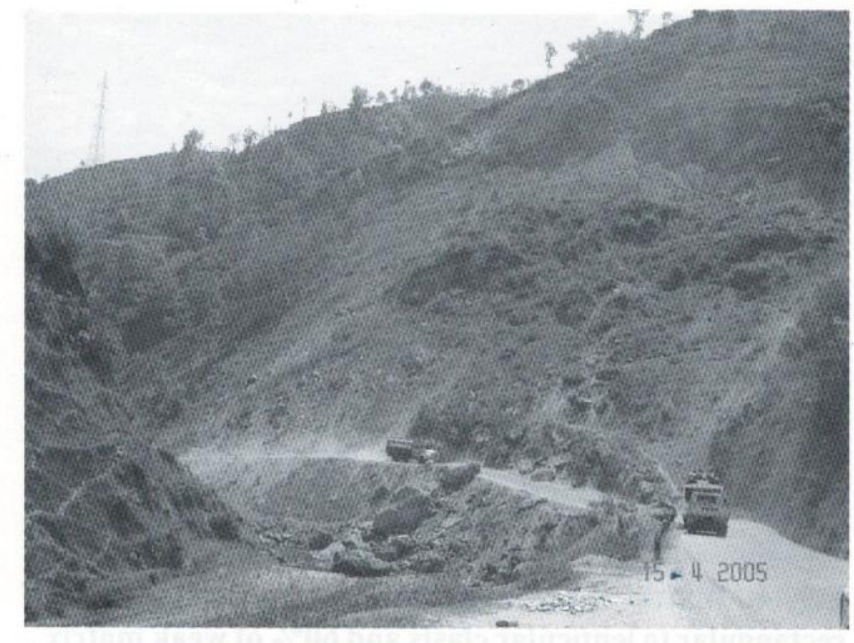

Fig. 7: Dolalghat Landslide which destroyed Arniko Highway on July 2003

upper inclined shaft section was influenced by several minor brittle shear zones. The overbreak occurred only in the blocky brittle shear or fault zones with a considerable amount of seepage. The shear zone contains sheared and fractured gneiss clasts in weak silty sand matrix (Sunuwar 2003). This shear zone is about $35 \mathrm{~m}$ thick and acts like an aquifer.

\section{Modi Khola Hydroelectric Project}

Two overbreaks in brittle shear zones were encountered in the pressure tunnel of the Modi Khola Hydroelectric Project (Paudel et al. 1998). They were characterised by fully decomposed soft fault gouge and shattered fault breccia containing a considerable amount of clay. One of the weak zones was $32 \mathrm{~m}$ thick and had a high inflow of groundwater since the pressure tunnel alignment was $7-10 \mathrm{~m}$ below the riverbed. A heading and benching method was followed for further excavation, pre-reinforced by forepoling: Its progress was very slow (i.e. $2-3 \mathrm{~m}$ per week) and took 10 months to cross this $85 \mathrm{~m}$ long shear or fault zone (Sharma 2000). The project schedule was delayed by this overbreak and the cost of rock support was increased.

\section{Rock squeezing}

Rock squeezing is a common problem in the Nepal Himalaya while tunnelling through the clayey brittle shear or fault zone (Table 2) containing mainly non-swelling clay (Sunuwar 2002). It reduces the cross-section of a tunnel due to time-dependent deformation of rock. It may stop or continue for a long time. In a worse case the tunnel can collapse. To overcome these problmes, time-consuming and expensive measures (e.g. reshaping and re-supporting of the tunnel) are required.

\section{Khimti I Hydropower Project}

In the Khimti I Hydropower Project, rock squeezing problems were encountered in clayey brittle shear or fault 
Table 1: Major overbreak records of the Khimti Hydropower Project (Sunuwar 2003)

\begin{tabular}{|c|c|c|c|}
\hline Location & Date of occurrence & Size $(\mathbf{x b x h}) \mathrm{m}^{3}$ & Shear or fault zone \\
\hline $\begin{array}{l}\text { Adit 1, Headrace, } \\
\text { Downstream (D/S) } \\
\text { Chainage (Ch.) } 344-363 \mathrm{~m} \\
\text { Ch.330-390m }\end{array}$ & $\begin{array}{l}29 \text { August } 1997 \\
18 \text { September } 1997\end{array}$ & $\begin{array}{c}19 \times 5 \times 4 \\
60 \times 15 \times 20\end{array}$ & $\begin{array}{l}30 \mathrm{~m} \text { thick blocky brittle shear zone } \\
50 \mathrm{~m} \text { thick clayey brittle shear zone }\end{array}$ \\
\hline $\begin{array}{l}\text { Adit 2, Headrace, } \\
\text { downstream - } \\
\text { Ch. } 230-260 \mathrm{~m}\end{array}$ & 12 August 1997 & $30 \times 12 \times 15$ & $25 \mathrm{~m}$ thick clayey brittle shear zone \\
\hline $\begin{array}{l}\text { Adit 3, Ch.194-210 m } \\
\text { Headrace D/S, Ch.12-26 m }\end{array}$ & $\begin{array}{l}\text { 19 September } 1998 \\
31 \text { October } 1998\end{array}$ & $\begin{array}{l}16 \times 12 \times 10 \\
14 \times 12 \times 16\end{array}$ & $\begin{array}{l}20 \mathrm{~m} \text { thick clayey brittle shear zone } \\
30 \mathrm{~m} \text { thick blocky brittle shear zone }\end{array}$ \\
\hline Adit 4 (Old), Ch.44-50 m & 9 February 1995 & $6 \times 7 \times 15$ & $15 \mathrm{~m}$ thick clayey brittle shear zone \\
\hline Adit 4 (New), Ch.44-50 m & 18 August 1996 & $6 \times 7 \times 9$ & $20 \mathrm{~m}$ thick blocky brittle shear zone \\
\hline Adit 5, Ch.110-115 m & 15 December 1994 & $5 \times 6 \times 8$ & $15 \mathrm{~m}$ thick clayey brittle shear zone \\
\hline $\begin{array}{l}\text { Old upper pressure shaft } \\
\text { Ch. } 186 \mathrm{~m} \text { onwards } \\
\text { New upper pressure shaft } \\
\text { Ch. } 352-364 \mathrm{~m}\end{array}$ & 19 April 1997 & $12 \times 15 \times 10$ & $35 \mathrm{~m}$ thick clayey brittle shear zone \\
\hline Tailrace, Ch.129-135 m & 6 June 1997 & $6 \times 7 \times 6$ & $20 \mathrm{~m}$ thick clayey brittle shear zone \\
\hline
\end{tabular}

Table 2: Tunnels under squeezing conditions in the Nepal Himalaya (Sunuwar 2002)

\begin{tabular}{c|l|l|c}
\hline S. N. & \multicolumn{1}{|c|}{ Name of project } & Shear zone or fault type & Deformation \\
\hline 1 & Adhi Khola, Tailrace tunnel, $2.2 \mathrm{~m}$ diameter & Clayey brittle shear zone & $25 \mathrm{~cm}$ \\
\hline 2 & Khimti I, Adit No. $5,3 \mathrm{~m}$ diameter & Clayey brittle shear zone & $40 \mathrm{~cm}$ \\
\hline 3 & Modi Khola, Pressure tunnel, $4.5 \mathrm{~m}$ diameter & Clayey brittle shear zone & $150 \mathrm{~cm}$ \\
\hline 4 & Kali Gandaki, Headrace tunnel, $8.5 \mathrm{~m}$ diameter & Clayey brittle shear zone & $100 \mathrm{~cm}$ \\
\hline 5 & Kulekhani I, Chakhel tunnel, $1.8 \mathrm{~m}$ diameter & Clayey brittle shear zone & $? ?$ \\
\hline 6 & Puwa Khola, Headrace tunnel, $2.5 \mathrm{~m}$ diameter & Clayey brittle shear zone & $30 \mathrm{~cm}$ \\
\hline 7 & Chilime, Headrace tunnel, $3.5 \mathrm{~m}$ diameter & Clayey brittle shear zone & $35 \mathrm{~cm}$ \\
\hline 8 & Indrawati, Headrace tunnel, $2.5 \mathrm{~m}$ diameter & Clayey brittle shear zone & $50 \mathrm{~cm}$ \\
\hline
\end{tabular}

zones during the excavation of various tunnel sections (Table 3 ). The zones were characterised by very weak, sheared, crenulated, altered, and decomposed rock and bands of clay gouge with strong angular clasts (Fig. 3). The shear or fault zones contain more than $80 \%$ of clay matrix and less than $20 \%$ of lenticular quartz clasts. The matrix is rich $(60-70 \%)$ in non-swelling clays such as illite and chlorite (Sunuwar 2002). The thickness of the shear or fault zones varies from $5 \mathrm{~m}$ to a maximum of $60 \mathrm{~m}$. The squeezing of walls was evidenced by the cracked and converging shotcrete whereas in some sections the invert was also heaving. According to the monitoring data, squeezing generally lasted for 5 to 6 months. The maximum deformation recorded was $40 \mathrm{~cm}$ (i.e. $13 \%$ of the tunnel diameter) in Adit 5 at Chainage $245 \mathrm{~m}$ (Table 3). Tunnel excavation was very slow (i.e. $7-10 \mathrm{~m}$ per week) in the squeezing sections, where $25 \mathrm{~cm}$ thick fibrereinforced shotcrete with grouted rock bolts was provided to overcome the problem.

\section{Modi Khola Hydroelectric Project}

In the Modi Khola Hydroelectric Project, squeezing occurred between Chainage $20 \mathrm{~m}$ and $70 \mathrm{~m}$ of the pressure tunnel (Sunuwar 2005) where clayey brittle shear or fault zone was encountered. It consists of fully decomposed soft
Table 3: Some examples of squeezing in Khimti Hydropower tunnels (Sunuwar and Fowell 2001)

\begin{tabular}{l|l|l}
\hline Location & Deformation & $\begin{array}{l}\text { Shear or fault } \\
\text { zone }\end{array}$ \\
\hline $\begin{array}{l}\text { Adit 1 Headrace } \\
\text { Downstream (D/S), } \\
\text { Chainage (Ch.) } \\
465-620 \mathrm{~m}\end{array}$ & $50-170 \mathrm{~mm}$ & $\begin{array}{l}60 \mathrm{~m} \text { thick clayey } \\
\text { brittle shear zone }\end{array}$ \\
\hline $\begin{array}{l}\text { Adit } 2 \text { Headrace D/S } \\
\text { Ch.1276-1280 m }\end{array}$ & $60 \mathrm{~mm}$ & $\begin{array}{l}20 \mathrm{~m} \text { thick clayey } \\
\text { brittle shear zone }\end{array}$ \\
\hline $\begin{array}{l}\text { Adit 3 Headrace U/S } \\
\text { Ch.178-234 m }\end{array}$ & $40-63 \mathrm{~mm}$ & $\begin{array}{l}15 \mathrm{~m} \text { thick clayey } \\
\text { brittle shear zone }\end{array}$ \\
\hline $\begin{array}{l}\text { Adit } 4 \text { (Old) } \\
\text { Ch.58-76 m }\end{array}$ & $100-300 \mathrm{~mm}$ & $\begin{array}{l}18 \mathrm{~m} \text { thick clayey } \\
\text { brittle shear zone }\end{array}$ \\
\hline Adit 5 Ch.222-245 m & $300-400 \mathrm{~mm}$ & $\begin{array}{l}10 \mathrm{~m} \text { thick clayey } \\
\text { brittle shear zone }\end{array}$ \\
\hline $\begin{array}{l}\text { Tailrace D/S } \\
\text { Ch.68-80 m }\end{array}$ & $2.4 \mathrm{~mm}$ & $\begin{array}{l}50 \mathrm{~m} \text { thick clayey } \\
\text { brittle shear zone }\end{array}$ \\
\hline
\end{tabular}


fault gouge and shattered clasts. The squeezing caused buckling of steel sets on the right wall and occasionally at the crown. In some sections ground heaving was also observed. The squeezing was active for 4 months and a maximum deformation of $150 \mathrm{~cm}$ (i.e. $30 \%$ of the tunnel diameter) was recorded (Sharma 2000). Umbrella grouting and steel sets with shotcrete were applied for a primary support. The replacement of deformed steel sets and tunnel reshaping incurred extra costs as well as construction delays.

\section{CONCLUSIONS}

Most serious geological problems in the development of infrastructures are generated by shear zones and faults. The problems related to shear or fault zones are due to their contrasting properties in the weak matrix with strong rock fragments and the presence of groundwater.

Generally cataclastic rocks and brittle shear or fault zones are identified in the Nepal Himalaya. Among them the brittle shear or fault zones are geotechnically problematic. Such zones are characterised by sheared, shattered, and folded loose rock containing strong, lenticular to angular, randomly orientated clasts supported by soft and weak matrix. They can be divided into clayey (with less than $25 \%$ of clasts) and blocky (with $25-75 \%$ of clasts) types. Such shear or fault zones require a detailed and careful engineering geological investigation before the construction of infrastructures.

\section{REFERENCES}

Hoek, E., 1999, Review of Geotechnical Issues Related to the Kali Gandaki A Hydroelectric Project, Nepal. Unpublished, Morrison Knudsen International Inc, pp. 1-11.
Medley, E. W, 1999, Systematic characterization of Melange Bimrocks and other chaotic soil/rock mixtures. Pub. Journal of Engineering Geology, Geomechanics and Tunnelling, Rock and Soil Engineering, 3/99, Felsbau 17, No. 3/1999, pp. 152-162.

Paudel, T. R., Dangol, V., and Sharma, R. H, 1998, Construction phase engineering geological study in Modi Khola Hydroelectric Project, Parbat district, western Nepal. Pub. Journal of Nepal Geological Society, 1998, Vol. 18, pp. 343-355.

Sharma, R. H, 2000, Construction Report of the Modi Khola Hydroelectric Project, Himal Hydro and General Construction Limited, Nepal. Unpublished pp. 33-35.

Sunuwar, S. C. and Fowell, R. J, 2001, Rock squeezing problems experienced in the Khimti Hydropower Project, Nepal. Proceedings of the ISRM Regional Symposium Eurock 2001, Espoo, Finland, 4-7 June 2001, edited by P Sarkka \& P. Eloranta. Pub. A. A. Balkema, Lisse, Netherlands, pp. 711716.

Sunuwar, S. C, 2002, Squeezing tunnels in Nepal: Case studies, Proceedings of ISRM Regional Symposium on "Advancing Rock Mechanics Frontiers to Meet the Challenges of 21st Century", 24-27 September 2002, New Delhi.

Sunuwar, S. C, 2003, Overbreak problem in the inclined pressure shaft of the Khimti I Hydropower Project in Nepal, World Tunnelling, Vol. 16 No. 6, July/August 2003, pp. 241-242.

Sunuwar, S. C, 2005, Geological problems in the hydropower development of Nepal: Case studies, Proceedings 6th International Conference on Development of Hydropower: A Major Source of Renewable Energy, 7-9 June 2005, Kathmandu, organised by Irrigation Board of India \& Nepal Electricity Authority, pp. 130-141.

Upreti, B. N., 2002, Engineering Geology for Developing Countries: Experience from the Nepal Himalaya. Proceedings Ninth International Congress International Association for Engineering Geology and the Environment, Durban, South Africa, Edited by J.L. van Rooy \& C. A. Jermy, pp. 1-23.

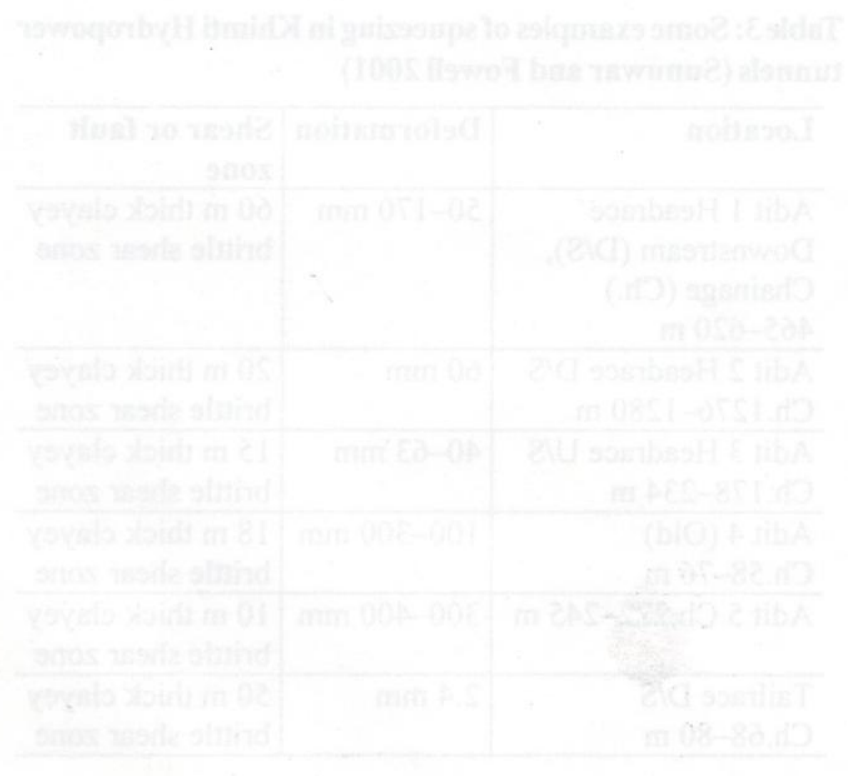

